\title{
Research on Interlocking Directorates in Family Business: Evidence from Scopus Bibliometric Data
}

\author{
Nawar Muneer J. Algthami and Nazimah Hussin
}

\section{ABSTRACT}

\begin{abstract}
We examined the trend of studies on interlocking directorates in family businesses using bibliometric data mined from the Scopus database. Search terms including "family business" and seven other variant terms (including family ownership) plus a wildcard (interlock*) yielded only 17 peer-reviewed papers written in the English Language, published between 1999 and 2020. We used graphical tools to summarise the data. Pearson's $r$ was employed to analyse the data on three of Scopus' bibliometric indicators (CiteScore, SCImago Journal Rank, and Source Normalized Impact per Paper) using JASP. The only 17 articles on interlocking directorates in family business poorly compare with the 4,792 articles returned when the wildcard was dropped. Thus, the data show that interlocking directorates in family businesses is a grossly neglected niche in the otherwise steadily maturing field of family business research. The distribution of the scanty literature by country of origin, research purpose pursued, theories employed as explanatory frameworks, the most frequently studied interlocking directorate typologies, and their respective implications were pointed out.
\end{abstract}

Keywords: Bibliometric data, CiteScore, Family business, Interlocking directorates, Scopus database.

\section{INTRODUCTION}

Interlocking directorates have excited researchers and scholars (especially those from economists and lawyers) for over 120 years. Fennema and Schijf [1] report that the very first work on directorate ties was a 1905 dissertation produced in Germany. Ten years later, Dixon [2] and Durand [3] in the United States published their work on the subject from socioeconomic and legal perspectives, respectively. In 1990, Kirkpatrick published a study on the research trends in the field using studies published between 1974 and 1988. He found that research on interlocking directorates has levelled off, suggesting that not much scholarship was invested in the area. He attributed the lacklustre scholarly output to data deficit. Kirkpatrick [4] hoped that the emergence of reliable, credible, and accessible data would reflate researchers' efforts in the field.

However, three decades after Kirkpatrick [4], research on interlocking directorates, notwithstanding the superlative availability of various databases on virtually every facet of corporate function, including board and director characteristics, is disappointingly modest. The paltry publication statistics presented in Caiazza and Simoni's [5] recent bibliometric analysis as the sum of all effort in the field supports this conclusion.

The less than satisfactory performance scorecard is reflected in every specialised field of inquiry where directorate ties play a significant role, including corporate governance [6], [7]. It is dismal with regard to the family business research niche. Indeed, research on interlocking
Submitted : July 31, 2021

Published : August 23, 2021

ISSN: $2507-1076$

DOI: $10.24018 /$ ejbmr.2021.6.4.1012

Nawar Muneer J. Algthami*

Azman Hashim International Business School, Universiti Teknologi Malaysia, 81310 Johor Bahru, Malaysia.

(e-mail: noray-m@hotmail.com)

Nazimah Hussin

Azman Hashim International Business

School, Universiti Teknologi Malaysia, 81310 Johor Bahru, Malaysia.

(e-mail: nazimah.k1@utm.my)

*Corresponding Author directorates is so neglected that a recent review on family business research with a focus on corporate governance [i.e., 8] did not even mention the construct at all. The situation is surprising, seeing that scholars have almost universally concurred that family businesses rely on close personal, social, and institutional relationships as mechanisms for survival and business development $[9,10]$. In response to this intriguing situation, we undertook this study to find evidence, however tenuous, from one of the largest (or the largest) databases of peer-reviewed scholarship, i.e., Elsevier's Scopus.

\section{CONSTRUCTS}

\section{A. Family Business}

We single out Shanker and Astrachan's [12] definition of the family business to delineate what we mean by the family business. They divided family businesses into three categories, depending on the degree of family involvement in the business. The first category is the broadest and includes family firms where the family has a low degree of involvement in the firm's operations but retains control over business strategy, and there is an intention to retain long-term employment in the family. The second category involves family firms where there is greater family involvement in the operations, so that family members manage the firm's affairs through its board and retain control and voting rights. The last category is the narrowest and contains family firms with the highest degree of involvement in operations, and family 
members dominate the board of directors. Family board members are directors related to the owning family by (i) blood, or (ii) marriage, or (iii) long professional employment relationship up to 10 years, or any combination of i-iii [13]. Any article indexed in the Scopus database that studies any of these categories of family firms plus the construct of interlocking directorates is included in this study.

\section{B. Interlocking Directorates}

Burt [10] defines interlocking directorates as "interorganisational connections through corporate boards of directors" [10]. The connection is created "when one individual sits on the board of directors of two or more companies" [14]. Heemskerk [15] remarked that "interlocking directorates tie together a corporate elite network that spans the corporate control centres of the economy" [15]. Thus, directorate tie is a mechanism that connects one firm to another through a board member having a seat on boards of several companies. Accordingly, we define interlocking directorates as the number of family business board members who sit on other firms' board(s). It is noteworthy that inter-corporate relationships not necessarily mediated through any board member are termed corporate networks in contradistinction to interlocking directorates. Thus, these are two distinct but related areas of study.

Family businesses cultivate directorate ties primarily to advance some interest or protect against some market adversities [16]. Easy access to material and no-material resources and political leverages are some of the benefits that family businesses gain through interlocking directorates [1719]. Directorate ties thus serve several purposes. It integrates family business owners into the network of clan alliances and serves as windows for mobilising tangible and intangible resources [20]. Also, interlocking directorates are mechanisms for disseminating corporate best practices in a given industry or geographic location [21], [22]. It crucially serves as a mechanism for maintaining cohesion in the family business [23]. Similarly, the work of Lee et al. [24] suggests that ties with external sources created through directorate ties could serve a family business very well in times of resource scarcity. Not least in importance, directorate ties also serves as an internal cohesion mechanism facilitating information sharing among group members [25].

\section{Interlocking Directorates in Family Business Research}

Scholarly interests in interlocking directorates arouse following the government's attempt to guard against unfair competitive practices and monopolistic tendencies of big corporations in the United States. The corporations practised interlocking ties to survive agency costs resulting from the dysfunctions of the business environment. Thus, it was business for the corporations while it was unfair competitive practices in the eyes of the authorities. The Sherman Antitrust Act of 1890 and the Clayton Act of 1914, which amended it, deals with directorate ties among the corporates of the United States [3], [26]. Outside the United States, governments have used company regulations to cap the number of interlocks per board member or the board itself. For example, Article 17(c) of Saudi Arabia's Corporate Governance Regulation [27] places a ceiling on the number of boards a person may sit on to five.
The statutes and regulations related to directorate ties, such as those mentioned above, were crafted to deal with monopolistic practices of big business and thus hardly contemplate family businesses. However, directorate ties in family business arouse for different reasons. For a long time, scholars believe that kinship is one of the primary and most basic catalysing factors for interlocking directorates [28], especially in family businesses [29]. Nevertheless, family business research typically adopts or at best adapt practices developed within the non-family businesses research contexts in the study of directorate ties. In this study, the researchers highlighted the methods, theories and perspectives researchers follow in study interlocking directorates in family businesses.

\section{Methodology}

The articles on interlocking directorates used in this bibliometric study were sourced from the Scopus database, arguably the largest abstract and citation database of peerreviewed journals articles, books, and conference proceedings, especially in comparison to its rival Web of Science database [30], [31]. Pearson's $r$ and its scatter plots and heatmap were produced using JASP [32] based on the Scopus data collected. The charts were processed using Microsoft Excel.

\section{A. Search Terms and Query Strings}

Formulating an exact query string is the first task a researcher does when doing a bibliometric investigation [33]. We used a simple inclusion criterion: We included any study in the Scopus database on family business that substantially addresses directorate ties. Thus, a query string based on "family business" and seven other variants of the construct (including family ownership) AND a wildcard (interlock*) yielded only 17 peer-reviewed papers written in the English Language and published between 1999 (when the first article on family business interlocks was published) and 2020. The Boolean operator "AND" ensures that only articles on interlocking directorates plus family business are returned. It is noteworthy that we run a search substituting "interlock*" with "network" because some researchers (e.g., [34], [35]) use "director network" as synonyms for interlocking directorates. However, the three articles returned were already captured in the first search.

Appendix I shows details of the query strings used and their associated constructs. Additionally, we searched for "family business" and its variants covering 1999-2020 and limited to English Language journal articles to get the magnitude of Scopus-indexed papers in the field of family business research. The query yielded 4,792 articles, 3,000 of which comes from the years concomitant that yield the 17 articles on directorate ties in family businesses. Similarly, research articles on "interlocking directorates" outside the family business domain were searched to compare the magnitude of interlocking directorship research in the family business domain vis-à-vis the entire research output in the field. The results yielded 326 articles, 200 of which were from the years our 17 articles were extracted. 


\section{B. Data}

Data were extracted from the Scopus database using a series of query strings shown in Appendix I. Additional data on journal performance and article quality (associated with the 17 articles analysed in this study) were also extracted. Appendix II shows the 2020 data on the indicators of the journals' performance (CiteScore Quartile, CiteScore, and SCImago Journal Rank) as well as the quality of the articles coming from the journals (Source Normalized Impact per Paper, and Citation Counts), arranged in descending order based on the articles' citation counts. These are the two broad categories of bibliometric indicators used in assessing scholarly publications [36].

Summaries of the 17 studies on directorate ties were shown in Appendix III. The classification of interlocking directorates used in the summaries is informed by Brennecke and Rank's [37] three typologies: sent interlocks, received interlocks, and undirected (or neutral) interlocks. However, we also extracted other important features, including study type and methods used, variables investigated, theories employed, firms' country of origin and status, and data sources.

\section{RESULTS AND INTERPRETATIONS}

Results obtained on analysis of bibliometric data hardly address any meaningful objectives unless interpreted in the light of a clearly defined context [38]. In this study, we interpret the results of our analysis in light of the trend in directorate ties in family business research. We begin with understanding the quality of the journals that so far published research on directorate ties in family businesses.

\section{A. Quality of the Scopus Journals that Published Research on Directorate Ties in Family Businesses}

We relied on three Scopus' bibliometric indicators (i.e., CiteScore Quartiles 2020, CiteScore 2020, and SourceNormalised Impact per Paper 2020) as well as the SCImago Journal Rank 2020 (derived from Scopus data) in gauging the relative qualities of the 14 journals that published research on interlocking directorates in family businesses as at 2020. Data for the four indicators are presented in Table I. The CiteScore gives the average citations per document that a journal (or other sources) receives over the last four years [39]. The CiteScore Quartile indicates a journal's (or other sources') CiteScore performance within their assigned subject category or categories [40]. The Source-Normalised Impact per Paper is an indicator of a journal's (or other source's) contextual citation impact and is computed by weighting the source's citations based on the total number of citations in the source's assigned subject category or categories [41]. The SCImago Journal Rank assesses the weighted citations received by a journal (or other sources) based on their assigned subject category or categories [42]. We determine the degree of association between the metrics (except the CiteScore Quartiles, as it yields categorical data) using Pearson correlation analysis. Pearson's $r$ describes the linear correlation between two variables [43].
TABLE I: QCS, SJR, CS, AND SNIP VALUES FROM SCOPUS

\begin{tabular}{|c|c|c|c|c|c|}
\hline SN & Journal Title & CSQ & SJR & $\mathrm{CS}$ & SNIP \\
\hline 1 & $\begin{array}{l}\text { Entrepreneurship: Theory and } \\
\text { Practice }\end{array}$ & Q1 & 5.365 & 17.7 & 4.836 \\
\hline 2 & $\begin{array}{l}\text { Academy of Management } \\
\text { Journal }\end{array}$ & Q1 & 11.193 & 14.2 & 4.230 \\
\hline 3 & Journal of World Business & Q1 & 3.607 & 10.8 & 2.801 \\
\hline 4 & Organisation Studies & Q1 & 4.441 & 7.7 & 2.669 \\
\hline 5 & $\begin{array}{l}\text { Journal of Family Business } \\
\text { Strategy }\end{array}$ & Q1 & 1.557 & 7.1 & 1.818 \\
\hline 6 & Socio-Economic Review & Q1 & 1.737 & 5.6 & 2.495 \\
\hline 7 & Sustainability & Q1 & 0.612 & 3.9 & 1.242 \\
\hline 8 & $\begin{array}{l}\text { Cross Cultural \& Strategic } \\
\text { Management }\end{array}$ & Q1 & 0.545 & 3.8 & 0.918 \\
\hline 9 & $\begin{array}{l}\text { Corporate Governance: An } \\
\text { International Review }\end{array}$ & Q1 & 0.866 & 3.7 & 1.241 \\
\hline 10 & $\begin{array}{l}\text { Management and } \\
\text { Organization Review }\end{array}$ & Q1 & 0.896 & 3.6 & 1.203 \\
\hline 11 & $\begin{array}{l}\text { Journal of Economic } \\
\text { Interaction and Coordination }\end{array}$ & Q2 & 0.416 & 2.6 & 0.979 \\
\hline 12 & $\begin{array}{l}\text { Local Economy: The Journal of } \\
\text { the Local Economy Policy Unit }\end{array}$ & Q2 & 0.391 & 1.8 & 0.679 \\
\hline 13 & $\begin{array}{l}\text { Indian Journal of Corporate } \\
\text { Governance }\end{array}$ & Q3 & 0.227 & 1.8 & 1.350 \\
\hline 14 & $\begin{array}{l}\text { Histoire sociale / Social } \\
\text { History }\end{array}$ & Q3 & 0.113 & 0.2 & 0.290 \\
\hline
\end{tabular}

KEY: CSQ = CiteScore Quartile; SJR = SCImago Journal Rank; CS = CiteScore; SNIP = Source Normalized Impact per Paper.

Source: Scopus (https://www.scopus.com/), 2021.

In Table II, the Pearson's $r$ was computed for the CiteScore, the Source-Normalised Impact per Paper, and the SCImago Journal Rank, based on data the 2020 bibliometric indicators of the 14 journals indexed in the Scopus database. The combination of indicators with the highest correlation coefficient is the CiteScore 2020 versus Source-Normalised Impact per Paper $2020(r=0.97)$. However, while the Pearson's $r$ for the CiteScore 2020 versus SCImago Journal Rank 2020 ( $r=0.83$ ) and SCImago Journal Rank 2020 versus Source-Normalised Impact per Paper 2020 ( $r=0.86)$ were robust, the results of the bivariate normality test using the Shapiro-Wilk test for bivariate normality [44] suggest that the data from which the correlation coefficients were computed may not be normally distributed (Table III), thereby detracting from their intrinsic worth.

TABLE II: PEARSON'S CORRELATIONS

\begin{tabular}{lccccc}
\multicolumn{7}{c}{ TABLE II: PEARSON's CORRELATIONS } \\
& $n$ & $\begin{array}{c}\text { Pearson's } \\
r\end{array}$ & $p$ & $\begin{array}{c}\text { Lower } \\
\text { 95\% CI }\end{array}$ & $\begin{array}{c}\text { Upper 95\% } \\
\text { CI }\end{array}$ \\
\hline \hline CS - SJR & 14 & 0.83 & $<.001$ & 0.55 & 0.95 \\
CS - SNIP & 14 & 0.97 & $<.001$ & 0.90 & 0.99 \\
SJR - SNIP & 14 & 0.86 & $<.001$ & 0.60 & 0.95 \\
\hline \hline
\end{tabular}

TABLE III: SHAPIRO-WILK TEST FOR BIVARIATE NORMALITY

\begin{tabular}{lcc}
\hline \hline & Shapiro-Wilk & $p$ \\
\hline \hline CS - SJR & 0.53 & $<.001$ \\
CS - SNIP & 0.87 & .040 \\
SJR - SNIP & 0.59 & $<.001$ \\
\hline \hline
\end{tabular}

The Pearson's correlation coefficient matrix (Table II) is depicted as scatter plots (Fig. 1 (a-c)) and is also expressed as a heatmap (Fig. 1 (d)). The scatter plots and the heatmap show that CiteScore 2020 values correlate more strongly with the Source-Normalised Impact per Paper 2020 values (and express each other better) than with SCImago Journal Rank 2020 values (Fig. 1). According to the message of the heatmap, the Pearson's $r$ between CiteScore 2020 and SJR, between CiteScore 2020 and Source-Normalised Impact per Paper 2020, and between SCImago Journal Rank 2020 and 
Source-Normalised Impact per Paper 2020 approaches one. Thus, either of the $r$ values of CiteScore 2020 and SourceNormalised Impact per Paper 2020 can be used as there is no difference in the information they contained. However, considering the results of the Shapiro-Wilk test for bivariate normality (Table III), which revealed that the bibliometric indicators follow a normal distribution (except for SCImago Journals Rank), only the $r$ values of CiteScore 2020 versus Source-Normalised Impact per Paper 2020 could be said to express each other. The null hypothesis of the Shapiro-Wilk test assumes a normally distributed population. Thus, the Pearson's $r$ for CiteScore 2020 versus SCImago Journal Rank 2020 and SCImago Journal Rank 2020 versus SourceNormalised Impact per Paper 2020 reject their respective null hypotheses favouring the alternative hypotheses. This is visualised in the scatter plots (Fig. 1 (a-c)).

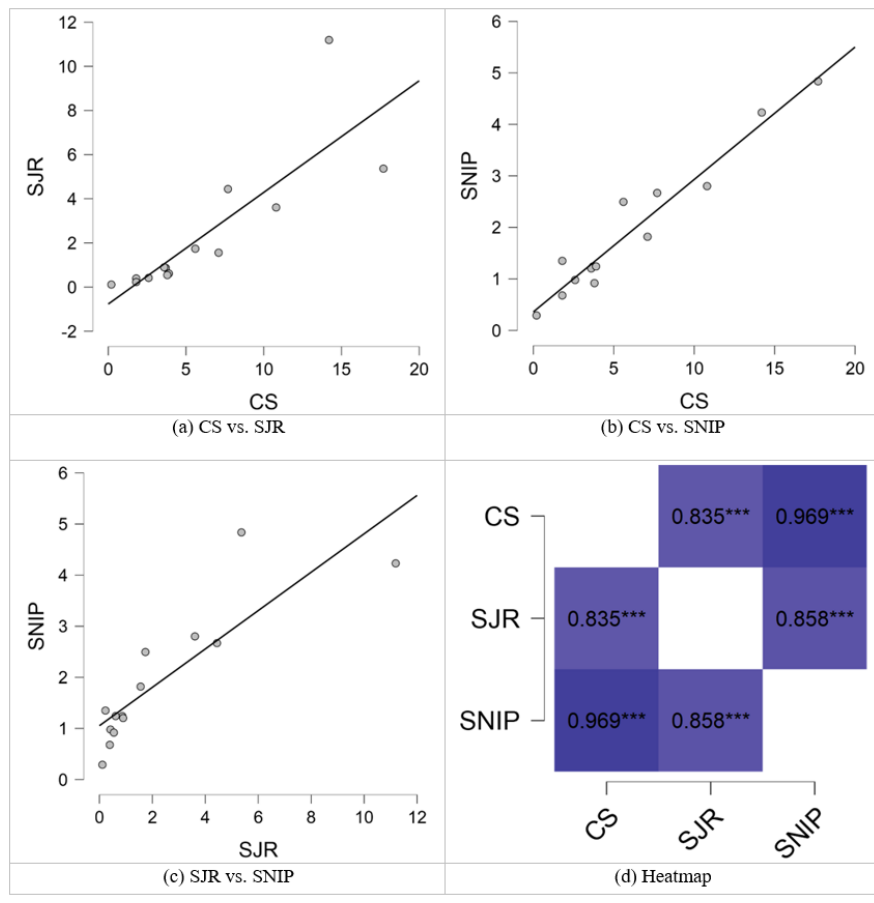

Fig. 1. Scatter Plots of Pearson's Correlations and Heatmap.

In view of the foregoing, we utilised the values from CiteScore 2020 and Source-Normalised Impact per Paper 2020 to gauge the quality of the journals in which the research on interlocking directorates in family businesses was published. Accordingly, the results of this study seem to endorse Entrepreneurship: Theory and Practice, Academy of Management Journal, and Journal of World Business as the top three journals [having mean CiteScore 2020 of 14.23: see Table X] that have so far published research on interlocking directorates in family businesses. These are followed by three more journals (with a mean CiteScore 2020 of 6.80): Organization Studies, Journal of Family Business Strategy, and Socio-Economic Review. It is noteworthy that the lowestranked of the 14 journals is an international journal on sociohistorical research. As noted elsewhere in this paper, researchers are tuning in to organisational historiography to understand better organisational dynamics and how they evolve and impact current practices. Further, we noted that the journal from India - a country that seems to produce more research on family business interlocking directorate than the
United States - is ranked low on the CiteScore 2020 metric. Why?

One heart-warming result of this study relates to the quality of the journals in which most of the research on directorate ties in family businesses were published. We extracted the CiteScore Quartiles for the journals based on their 2020 CiteScore Highest Percentiles: "Q1 (99-75th percentiles), Q2 (74-50th percentiles), Q3 (49-25th percentiles), and Q4 (240th percentiles)" [40]. Fig. 2 shows that $72 \%$ of the studies were published in Q1 journals. None belongs to the $4^{\text {th }}$ Quartile. The high quality of the journals where research on directorate ties in family businesses was published is an important assurance of high quality, high reputation, and high visibility the published articles should enjoy. Nevertheless, research in that niche from the family business research domain is yet to register. This could be in the CiteScore 2020 statistics, which show the 4-year average citation counts for articles from a given journal.

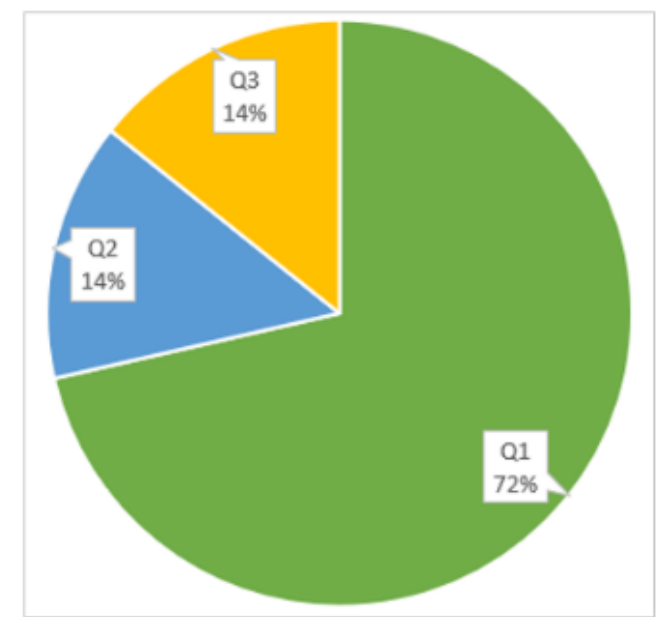

Fig. 2. Distribution of Journals by Quality.

\section{B. Family Business Research and Directorate Ties}

The data extracted from Scopus explicitly indicates that directorate tie in family business research is a barely touched but crucial niche in the family business research field. Indeed, six reviews on family business research [8], [45]-[49] did not mention anything about interlocking directorates, even by way of suggestion for future research. Even the three reviews (i.e., [45]-[47]), which are explicitly all about the future of family business research, did not foresee the significance of the need for more research into interlocking directorships in family businesses. It is thus surprising that while family businesses are known for their close-knit structure based on interrelationships among business interests, researchers have barely looked into the dynamics of such interrelationships from the board of directors' perspective. A comparison of the research output on directorate ties in family businesses with non-family businesses, curated in the Scopus database (Fig. 3 ), strongly buttresses the neglected state of research on board interlocks in family businesses. 


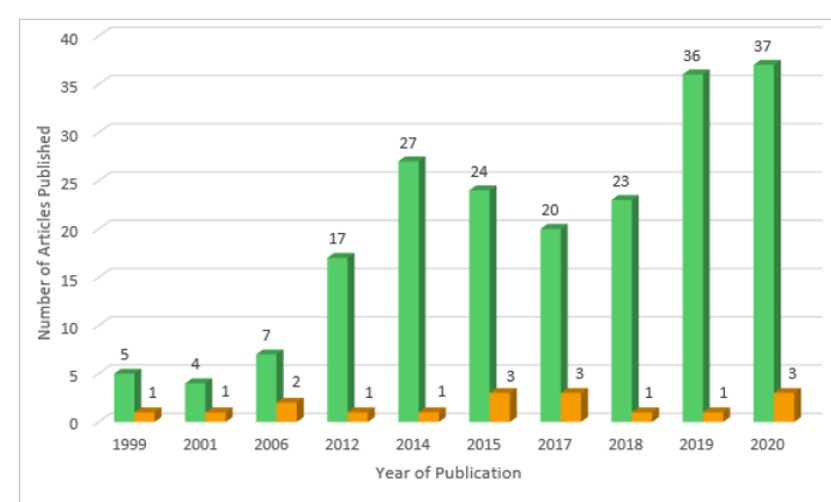

=" "Interlocks" - "Family Business" aㅐ "Family Buisiness" + "Interlock"

Fig. 3. Studies on Interlocking Directorate within Family and Non-Family Businesses.

\section{Types of Family Business Research}

An emerging consensus among researchers is that family businesses are heterogeneous and take on several characteristics that differ from place to place and culture [50][52]. Alrubaishi et al. [53] recently affirm that culture plays a "critical and pervasive influence" on the way businesses are administered. Similarly, Machek [54] decry the neglect of country of origin and ownership in family business research, which he sees as an open window wherethrough bias crept in, especially if the family firms studied have subsidiaries spread across national borders but were sampled as "family business." Thus, using any given set of culturally or geographically influenced characteristics of family businesses as selection criteria may enhance understanding of the unique factors impacting firm performance and limit generalisability to that cultural milieu or geographical area. However, without discounting the powerful influence of culture and country of origin on the characteristics and behaviours of family businesses, we elect to group them under the listed and non-listed categories [8], a schema relatively independent of cultural and locational differences.

Azila-Gbettor et al. [8] observed that research on nonlisted family firms focused on few indicators of ownership and board characteristics, while research on listed firms is dominated by studies using financial indicators. Non-listed family businesses are not listed on any stock exchange and whose are therefore not available for public subscription but are held by members of a family. On the other hand, listed family firms are listed on the stock exchange through which their shares are bought and sold by the investing public. Fig. 4 (a) shows that most of the firms in this study are listed on the stock exchanges of their respective countries of origin. Non-listed family firms are in the minority. This is surprising as the literature indicates that most economies are dominated by family businesses [55], a significant portion of which are non-listed.

It is also noteworthy that the country with the most family board interlocks studies (Fig. 4 (b)) come from the developing world (India). However, the United States, a country from the developed economic category, topped the list of countries with many interlocking directorate studies in non-family business (Fig. 5). Thus, research output on interlocking directorates in family businesses seems to be higher in developing countries, while board interlocks research in nonfamily businesses comes from developed economies. This is also surprising as the 32.4 million family businesses in the
United States contribute $87 \%$ of business tax returns [56]. With such a massive contribution to the US economy, one would expect the existence of robust directorate ties between United States' family business boards, which would have, in turn, triggered researchers' intense interest. However, our data seem to suggest otherwise. Is that the result of the atomisation of the United States' corporate elite, as Mizruchi [57] famously documented? For now, developing economies like India's seem to churn out more research on family business directorate ties (in percentage terms, Fig. 5) than the very bastion of family businesses (United States).
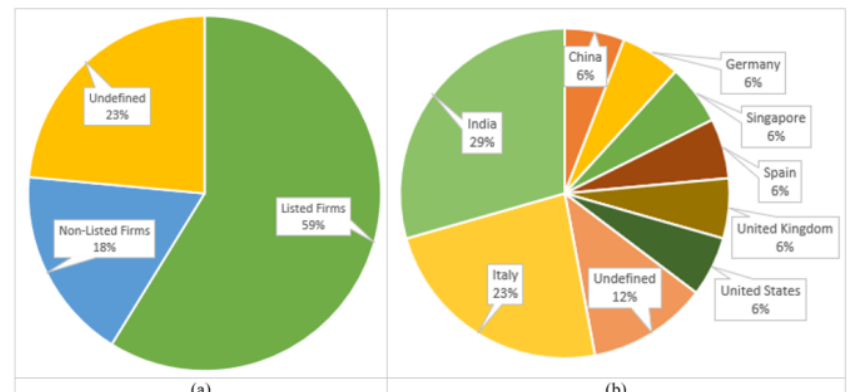

Fig. 4. Distribution of Family Businesses by (a) Status and (b) Country of Origin.

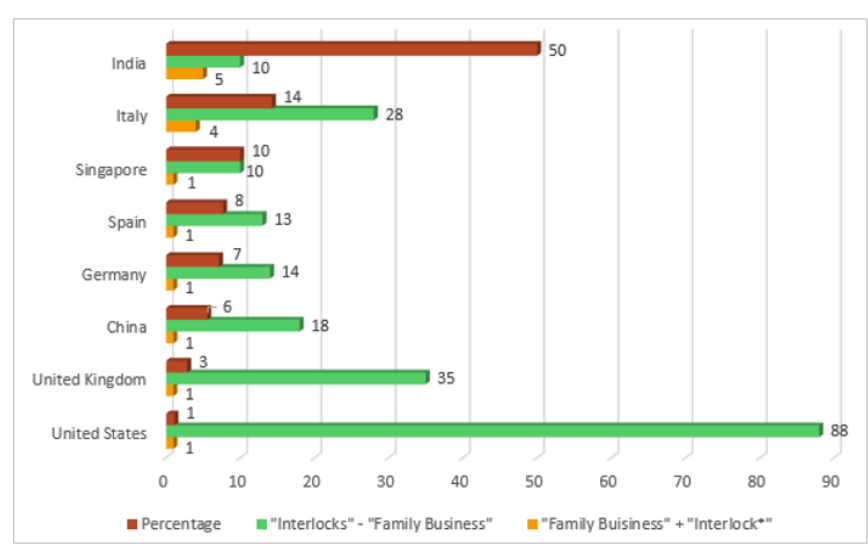

Fig. 5. Studies on Interlocking Directorate within Family and Non-Family Businesses by Country of Origin.

\section{Family Business Research and Interlocking}

We classified the 17 individual articles analysed in this study by purpose. Yazdani et al. [58] highlighted seven alternative classification systems from which we selected the one based on purpose. The purpose-based classification schema grouped scientific papers into three: explanatory, exploratory, and descriptive groups [see Fig. 6; details in Appendix III]. We followed this classification schema because of the tiny number of articles in our sample. Nevertheless, we will draw on the method-based classification approach in discussing the results.

A significant portion of the papers reviewed (53\%, Fig. 6) consists of explanatory studies seeking to unravel the causal mechanisms. The exploratory papers seek to answer the how or why behind the business processes, decisions, and behaviours [59] in family businesses studied. These papers collected data through primary or secondary surveys and utilised correlation analysis in processing the data. The other types of research papers in our sample are descriptive and exploratory research. The exploratory papers mainly used survey and secondary data and were carried out to determine 
possible relationships between variables in a set of data to develop further knowledge about the variables [60]. The descriptive papers are case studies and focus on single variables each. It is used in conjunction with the case method because it is the only research design that studies a single variable [61].

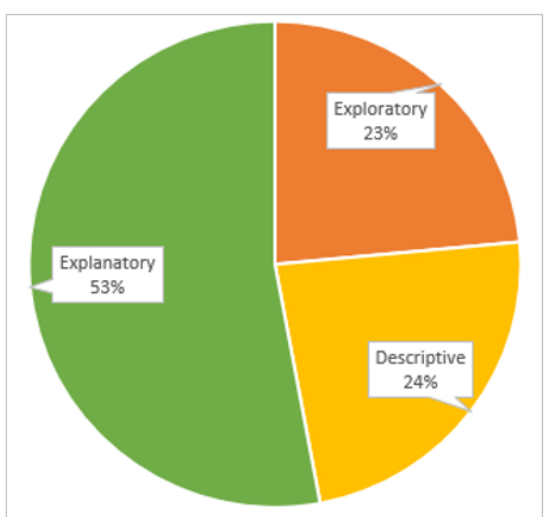

Fig. 6. Distribution of Articles by Purpose.

A crosstabulation of the three research purposes and the four types of research variables to which interlocking directorates was subjected in the 17 studies yielded interesting insights (Table IV). The Table was extracted from the data in Appendix III. Generally, our sampled articles overwhelmingly treated directorate ties as a predictor variable (Fig. 7 (a)). Few of the studies treated it as a criterion variable, and fewer still as a mediator. There is only one case of interlocking directorates as a moderating influence. When squared against the three forms of research by purpose (Fig. 7 (b)), it shows that exploratory research treats directorate ties as a predictor variable at least three times than the other variable types (Table IV). Concerning descriptive studies, the researchers seldom use interlocking directorates more as a criterion variable than as a predictor. This usage pattern aligns well with Siedlecki's [61] observation that descriptive studies can analyse a single variable. Overall, the results in Table IV seem to indicate a gap in the use of directorate ties as an interaction variable (i.e., a mediator and a moderator).

TABLE IV: Distribution OF ARTICLES By STUDY PURPOSES AND TYPES OF VARIABLES

\begin{tabular}{ccccccccc}
\hline \multicolumn{7}{c}{ OF VARIABLES } \\
\hline \hline \multirow{7}{*}{$\begin{array}{c}\text { Types of } \\
\text { Variable }\end{array}$} & \multicolumn{7}{c}{ Explanatory } & \multicolumn{7}{c}{ Exploratory } & \multicolumn{2}{c}{ Descriptive } & \multicolumn{2}{c}{ Total } \\
\cline { 2 - 9 } & $\mathrm{N}$ & $\%$ & $\mathrm{~N}$ & $\%$ & $\mathrm{~N}$ & $\%$ & $\mathrm{~N}$ & $\%$ \\
\hline \hline $\begin{array}{c}\text { Predictor } \\
\text { Variable }\end{array}$ & 6 & 35.29 & 2 & 11.76 & 1 & 5.88 & 9 & 52.94 \\
$\begin{array}{c}\text { Mediator } \\
\text { Variable }\end{array}$ & 0 & 0.00 & 0 & 0.00 & 1 & 5.88 & 1 & 5.88 \\
$\begin{array}{c}\text { Moderator } \\
\text { Variable }\end{array}$ & 1 & 5.88 & 1 & 5.88 & 0 & 0.00 & 2 & 11.76 \\
$\begin{array}{c}\text { Criterion } \\
\text { Variable }\end{array}$ & 2 & 11.76 & 1 & 5.88 & 2 & 11.76 & 5 & 29.41 \\
\hline Total & 9 & 52.94 & 4 & 23.53 & 4 & 23.53 & 17 & 100.00 \\
\hline \hline
\end{tabular}

Although research on interlocking directorates in family businesses have not even taken off per se, it is noteworthy that the few available studies have covered an appreciable ground about what is so far studied of the concept in non-family business settings. For example, the intensity of directorate ties studied by Fennema and Schijf [1] is taken up further by one of the 17 papers (i.e., Piana et al. [62]) reviewed in this study. In this study, the typology of interlocking directorates, advanced in Brennecke and Rank [37] and consisting of sent interlocks, received interlocks, and undirected (neutral) interlocks as understood from the perspective of the focal firm under discussion, was used as a frame of reference. The first refers to directorate ties from the focal firm's board to another firm's board by a director with management responsibilities. The second describes a situation where a director with managerial duties from another firm interlocks with the focal firm. The third interlocking type refers to an outsider who belongs to neither of the firms he interlocks for and holds a management position in neither.
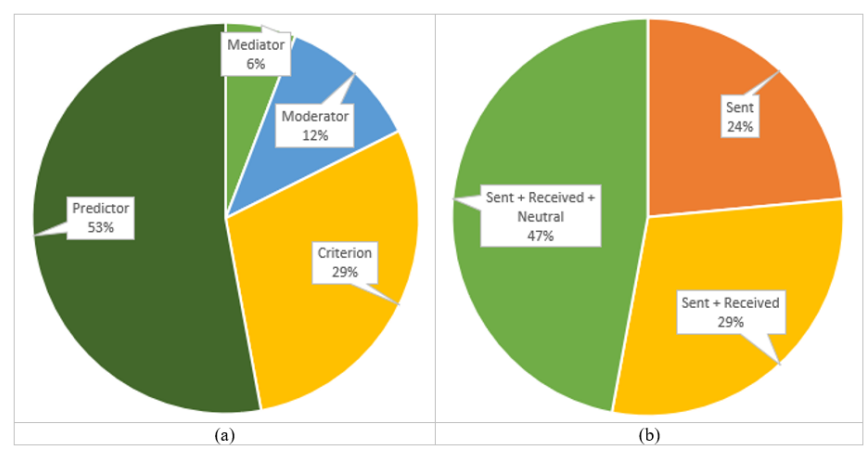

Fig. 7. Distribution of Articles by (a) Type of Variables and (b) Typology of Directorate Ties.

Fig. 7 (b) indicates that a significant portion of the family businesses studied used the whole gamut of directorate ties (sent, received, and neutral) to achieve several ends, as highlighted in section 2.2 of this paper. Indeed, only about a quarter of the firms studied in the articles use just one typology of the interlocking directorates, with three-quarters using at least a combination of the typologies. We can thus safely use these results to infer that directorate ties, though roundly neglected in the family business research domain, offer the prospects of sustainable research as most family businesses engage in one form of interlocking relationships or another. With a series of theories available to offer guidance, researchers are therefore called upon to address the many gaps identified in the field.

\section{E. Underpinning Theories}

The critical role of theory in family business research and the unquestioned need for its continual development has been recognised for a long time [63]. Theories provide the frameworks within which researchers guide develop testable propositions and explain empirical results [64]. The relevant question here is: What is the status of theory use in family business research? Zahra [65], while noting that the use of parts or multiple theories is steadily gaining momentum in family business research, he also notes that family researchers are wont to invoke the wrong theory in support of their studies or incorrectly invoke the correct theory or altogether fail to underpin the studies with any form of unifying theory. This prompts us to look into theory usage by researchers who have investigated interlocking directorates in family firms.

Analysis of the data on underpinning theories employed by researchers to explain interlocking directorate in the family business (see Fig. 8 (a)) indicates significant reliance on two theories (41\% of the articles) and more than two theories (12\%). Thus, $63 \%$ of the articles reviewed used two or more theories as explanatory frameworks. Indeed, Berge and 
Ingerman [66] and Cairney [67] observe that using multiple theories guarantees a more balanced perspective about the research phenomenon and guard against overreliance on any single theory and the danger inherent in its implicit assumptions. Nevertheless, a significant portion of the studies (35\%) were built on single theories. Sadly, a few of the articles $(12 \%)$ were crafted on no theories at all.

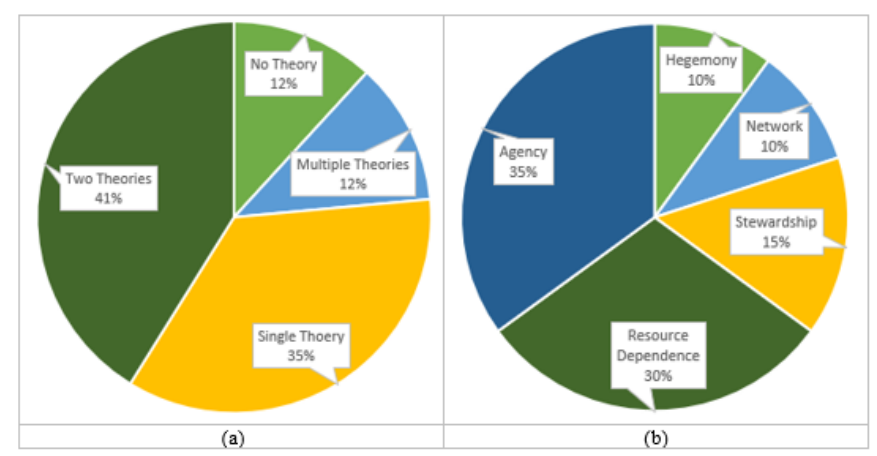

Fig. 8 (a) Distribution of Articles by Theory.

(b) Frequency of Specific Theory Use.

Further analysis of researchers' theory-use results revealed the specific theories they frequently rely upon to explain, predict, and or understand phenomena. Agency Theory and Resource Dependence Theory are the most frequently used (Fig. 8 (b)). Indeed, these theories are foundational to the field of corporate governance studies. Indeed, Zona et al. [68] combined the two theories in their study of interlocking directorates and provided a "higher-order explanation" of the directorate ties-firm performance relationships. Notwithstanding their popularity in family business research, these theories were propounded with non-family businesses in focus and thus may overlook the nuances peculiar to family businesses [48].

Less frequently used theories include stewardship, network, and hegemony theories. However, what theories were absent in the results of this study seems to be more pertinent to family business research than those featured. Indeed, it is surprising that none of the five "theories for family science" [system, life course, social exchange, structural functionalism, and symbolic interactionism] which Jennings et al. [49] laboriously explained in terms of their intellectual roots, core constructs, central premises, key assumptions, level of analysis, and fundamental question were not mentioned even in passing. Further, it is even more surprising that the property rights theory was barely employed in family business research since the primacy of family ownership in family businesses and its positive impact on firm performance rests squarely on the rights to family business property held by the owners [69].

Further, it is noteworthy that one of the papers reviewed in this study [70] takes a historical approach towards understanding family business. Family business researchers are now turning to history for a fuller understanding of family business dynamics, as evidenced by Family Business Review's dedication of its 2023 special edition to historydriven research in family business [see the call for papers in Suddaby et al. [71]]. Thus, we expect the sociological theory [72] and others to provide the necessary grid for organisational historiographical research in family businesses. It is hoped that contributors may address the paucity of research on directorate ties in family businesses.

\section{Conclusions}

This study tentatively mapped the extant research on interlocking directorates in family business based on the 17 articles extracted from the Scopus database. We used graphical tools to summarise the data and Pearson's $r$ and analyse the data on three Scopus' bibliometric indicators (CiteScore, SCImago Journal Rank, and Source Normalized Impact per Paper). The results seem to strongly suggest that research on directorate ties in family businesses is grossly neglected even though family businesses are known as cohesive economic units that rely overwhelmingly on family members networks not only to access needed resources but also to ensure the continuity of the business within the circle of the owner family. The distribution of the scanty literature by country of origin, research purpose pursued, theories employed as explanatory frameworks, and the directorate tie typologies most frequently studied, and their implications were pointed out.

\section{LIMITATION}

Our study relied on data exclusively derived from the Scopus database. While this database arguably is one of the largest (or the largest) multidisciplinary source of peerreviewed journal articles, conference proceedings, and books, it cannot be gainsaid that other studies on interlocking directorates in family businesses not captured in this study and which may have been indexed in other than the Scopus database (such as like Web of Science, PubMed, IEEE Xplore, and many others) will limit the generalisability of the tentative positions taken in this paper. 


\section{APPENDIXES}

APPENDIX I: CONSTRUCTS, SEARCH TERMS, AND SEARCH STRINGS

\begin{tabular}{|c|c|c|c|c|}
\hline $\mathrm{SN}$ & Constructs & Search Terms & Search Strings & Results \\
\hline 1. & Family Business & Family Business & $\begin{array}{l}\text { ((TITLE-ABS(“family firm” OR “family business” OR “family } \\
\text { enterprise” OR “family company” OR “family owned business” OR } \\
\text { "family-owned enterprise” OR “family ownership”)) AND } \\
\text { PUBYEAR > 1998 AND PUBYEAR < 2021 AND (LIMIT-TO } \\
\text { (SRCTYPE,“j”)) AND (LIMIT-TO (DOCTYPE,“ar”)) AND } \\
\text { (LIMIT-TO (LANGUAGE,"English”))). }\end{array}$ & 4,792 \\
\hline 2. & $\begin{array}{l}\text { Interlocking } \\
\text { Directorates }\end{array}$ & $\begin{array}{l}\text { Interlocking } \\
\text { Directorates }\end{array}$ & $\begin{array}{l}\text { (TITLE-ABS-KEY(interlock* OR "multiple board seats")) [as used } \\
\text { in addition to } 1 \text { above]. }\end{array}$ & In 1 above \\
\hline 3. & $\begin{array}{l}\text { Family Business } \\
\text { AND Interlocking } \\
\text { Directorates }\end{array}$ & $\begin{array}{l}\text { Family Business, } \\
\text { Interlocking } \\
\text { Directorates }\end{array}$ & $\begin{array}{l}\text { (TITLE-ABS-KEY("family firm" OR “family business" OR "family } \\
\text { enterprise" OR "family company" OR “family owned business" OR } \\
\text { "family-owned enterprise" OR "family ownership") AND TITLE- } \\
\text { ABS-KEY(interlock* OR "multiple board seats")). }\end{array}$ & 17 \\
\hline 4. & $\begin{array}{l}\text { Interlocking } \\
\text { Directorates AND } \\
\text { NOT Family } \\
\text { Business }\end{array}$ & $\begin{array}{l}\text { Family Business, } \\
\text { Interlocking } \\
\text { Directorates }\end{array}$ & 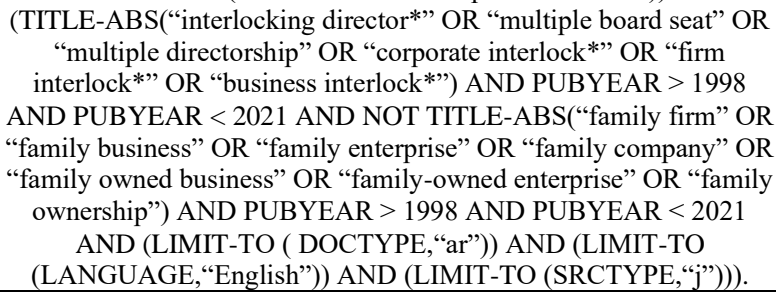 & 326 \\
\hline
\end{tabular}

Source: Scopus, 2021.

APPENDIX II: SEARCH OUTPUT AND CORRESPONDING JOURNAL METRICS (2020)

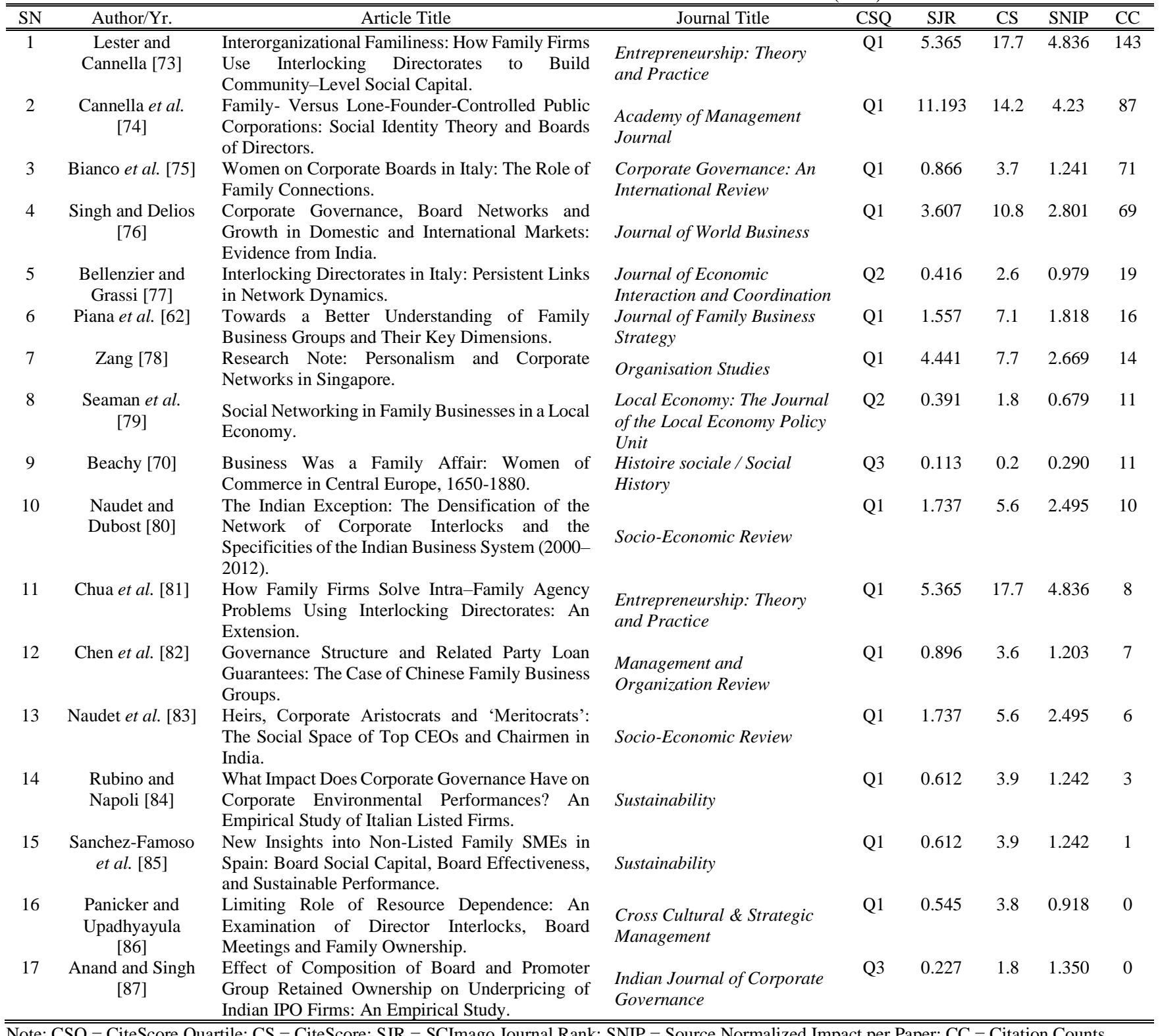

Source: Scopus, 2021. 
APPENDIX III: HIGHLIGHTS OF THE 17 SCOPUS-INDEXED ARTICLES ON INTERLOCKING DIRECTORATES IN FAMILY BUSINESSES

\begin{tabular}{|c|c|c|c|c|c|c|c|c|c|c|}
\hline SN & $\begin{array}{l}\text { Author/ } \\
\text { Year }\end{array}$ & $\begin{array}{l}\text { Study Method } \\
\text { \& Type }\end{array}$ & Objective(s) & $\begin{array}{c}\text { Sources \& Unit of } \\
\text { Analysis }\end{array}$ & Predictor Variable & $\begin{array}{c}\text { Mediator/ } \\
\text { Moderator/CV } \\
\end{array}$ & $\begin{array}{l}\text { Criterion } \\
\text { Variable } \\
\end{array}$ & $\begin{array}{c}\text { Underpinning } \\
\text { Theory }\end{array}$ & $\begin{array}{c}\text { Firm and } \\
\text { Country } \\
\end{array}$ & $\begin{array}{l}\text { Typology of } \\
\text { Interlocks }\end{array}$ \\
\hline 1 & $\begin{array}{l}\text { Sanchez- } \\
\text { Famoso et } \\
\text { al. [85] }\end{array}$ & $\begin{array}{l}\text { Empirical. } \\
\text { Explanatory } \\
\text { study. }\end{array}$ & $\begin{array}{l}\text { Investigate the moderated influence of } \\
\text { board interlocking and mediated effects } \\
\text { of board effectiveness in the } \\
\text { relationship between social capital } \\
\text { (internal and external) and firm } \\
\text { sustainable performance. }\end{array}$ & $\begin{array}{l}\text { Used survey data } \\
\text { from } 232 \text { CEOs. } \\
\text { Individual level of } \\
\text { analysis. }\end{array}$ & $\begin{array}{l}\text { Internal Social Capital; } \\
\text { External Social } \\
\text { Capital. }\end{array}$ & $\begin{array}{l}\text { Mediator: Board } \\
\text { Effectiveness, } \\
\text { Moderator: Board } \\
\text { Interlocking. }\end{array}$ & $\begin{array}{l}\text { Firm Sustainable } \\
\text { Performance }\end{array}$ & $\begin{array}{l}\text { Stewardship } \\
\text { Theory; } \\
\text { Resource } \\
\text { Dependence } \\
\text { Theory; Social } \\
\text { Capital Theory. }\end{array}$ & $\begin{array}{l}\text { Non-Listed } \\
\text { SMEs, Spain. }\end{array}$ & $\begin{array}{l}\text { The results implied the } \\
\text { existence of two types of } \\
\text { directorate ties: sent } \\
\text { interlocker and received } \\
\text { interlocker. }\end{array}$ \\
\hline 2 & $\begin{array}{l}\text { Panicker } \\
\text { and } \\
\text { Upadhyay } \\
\text { ula [86] }\end{array}$ & $\begin{array}{l}\text { Empirical. } \\
\text { Explanatory } \\
\text { study }\end{array}$ & $\begin{array}{l}\text { To investigate the moderating influence } \\
\text { of family ownership in interlocks/board } \\
\text { meeting frequency and } \\
\text { internationalisation in emerging } \\
\text { markets. }\end{array}$ & $\begin{array}{l}\text { Published economic } \\
\text { and financial data. } \\
\text { Organisational level } \\
\text { of analysis. }\end{array}$ & $\begin{array}{l}\text { Independent Director } \\
\text { Interlocks; Insider } \\
\text { Director Interlocks; } \\
\text { Meeting Frequency }\end{array}$ & $\begin{array}{l}\text { Moderator: Family } \\
\text { Ownership }\end{array}$ & $\begin{array}{l}\text { Level of } \\
\text { Internationalisa- } \\
\text { tion }\end{array}$ & $\begin{array}{l}\text { Resource } \\
\text { Dependence } \\
\text { Theory }\end{array}$ & $\begin{array}{l}\text { Listed Firms, } \\
\text { India. }\end{array}$ & $\begin{array}{l}\text { Used two types of } \\
\text { interlocking directorates: } \\
\text { received interlocker; sent } \\
\text { interlocker }\end{array}$ \\
\hline 3 & $\begin{array}{c}\text { Rubino } \\
\text { and Napoli } \\
\text { [84] }\end{array}$ & $\begin{array}{l}\text { Empirical. } \\
\text { Explanatory } \\
\text { study }\end{array}$ & $\begin{array}{l}\text { To investigate the effects of board of } \\
\text { directors and the ownership structures } \\
\text { of family and non-family firms on } \\
\text { corporate environmental performances. }\end{array}$ & $\begin{array}{l}\text { Published data AIDA } \\
\text { database and website } \\
\text { data. Organisational } \\
\text { level of analysis. }\end{array}$ & $\begin{array}{l}\text { Board Independence; } \\
\text { Directors' Interlocks; } \\
\text { Family Firm Status. }\end{array}$ & $\begin{array}{l}\text { Control Variables: Firm } \\
\text { Size; Firm Age; } \\
\text { Financial Performance. }\end{array}$ & $\begin{array}{l}\text { Corporate } \\
\text { Environmental } \\
\text { Performance. }\end{array}$ & $\begin{array}{l}\text { Agency-Theory; } \\
\text { Resource } \\
\text { Dependence } \\
\text { Theory. }\end{array}$ & $\begin{array}{l}\text { Listed Firms, } \\
\text { Italy. }\end{array}$ & $\begin{array}{l}\text { Focused on sent } \\
\text { interlocks only. }\end{array}$ \\
\hline 4 & $\begin{array}{l}\text { Anand and } \\
\text { Singh [87] }\end{array}$ & $\begin{array}{l}\text { Empirical. } \\
\text { Explanatory } \\
\text { study }\end{array}$ & $\begin{array}{l}\text { To investigate the impact of corporate } \\
\text { governance mechanisms (independent } \\
\text { directors' proportion, interlocking } \\
\text { directorships, female directors, and } \\
\text { promoter ownership) on IPO } \\
\text { underpricing. }\end{array}$ & $\begin{array}{l}\text { Published data from } \\
6 \text { sources. } \\
\text { Organisational level } \\
\text { of analysis. }\end{array}$ & $\begin{array}{l}\text { Independent Directors' } \\
\text { Proportion; } \\
\text { Interlocking } \\
\text { Directorships; Female } \\
\text { Directors; Ownership. }\end{array}$ & $\begin{array}{l}\text { Control Variables: } \\
\text { Subscription Ratio; } \\
\text { Listing Delay; Firm } \\
\text { Age; Issue Price } \\
\text { (Inverse). }\end{array}$ & $\begin{array}{l}\text { IPO } \\
\text { Underpricing } \\
\text { measured by } \\
\text { Market-Adjusted } \\
\text { Excess Return } \\
\text { (MAER). }\end{array}$ & $\begin{array}{l}\text { Signalling } \\
\text { Theory. }\end{array}$ & $\begin{array}{l}\text { Listed Firms, } \\
\text { India. }\end{array}$ & $\begin{array}{l}\text { Directorate ties proxied } \\
\text { for corporate reputation } \\
\text { (i.e., sent interlocker). }\end{array}$ \\
\hline 5 & $\begin{array}{l}\text { Naudet } e t \\
\text { al. }[83]\end{array}$ & $\begin{array}{l}\text { Empirical. } \\
\text { Primarily } \\
\text { exploratory } \\
\text { but also } \\
\text { descriptive. }\end{array}$ & $\begin{array}{l}\text { To analyse the social space inhabited } \\
\text { by Indian CEOs and Chairmen of the } \\
\text { top } 100 \text { Indian companies in } 2012 \\
\text { based on three categories of factors: } \\
\text { educational capital, family capital, and } \\
\text { directorate ties. }\end{array}$ & $\begin{array}{l}\text { Multi-source data. } \\
\text { Individual level of } \\
\text { analysis. }\end{array}$ & $\begin{array}{l}\text { Educational Capital; } \\
\text { Family Capital; } \\
\text { Interlocking } \\
\text { Directorates. }\end{array}$ & None & $\begin{array}{l}\text { Social Space of } \\
\text { Corporate Elite }\end{array}$ & $\begin{array}{l}\text { Theory not } \\
\text { stated. Top } \\
\text { Echelon Theory } \\
\text { is implied from } \\
\text { the results and } \\
\text { focus of the } \\
\text { study. }\end{array}$ & $\begin{array}{l}\text { Top } 100 \text { Listed } \\
\text { Firms, India. }\end{array}$ & $\begin{array}{l}\text { Interlocks as elite } \\
\text { network (insider and } \\
\text { outsider CEOs) based on } \\
\text { education, economic, } \\
\text { and social. Thus, it } \\
\text { focused on both sent and } \\
\text { received interlocks. }\end{array}$ \\
\hline 6 & $\begin{array}{l}\text { Singh and } \\
\text { Delios } \\
\text { [76] }\end{array}$ & $\begin{array}{l}\text { Empirical. } \\
\text { Explanatory } \\
\text { study }\end{array}$ & $\begin{array}{l}\text { To examine the individual and } \\
\text { combined effects of board structure, } \\
\text { network centrality through directorate } \\
\text { ties and ownership structure on a firm's } \\
\text { growth strategies. }\end{array}$ & $\begin{array}{l}\text { Data extracted from } 4 \\
\text { databases. } \\
\text { Organisational level } \\
\text { of analysis. }\end{array}$ & $\begin{array}{l}\text { Family Ownership; } \\
\text { Board Independence; } \\
\text { CEO Duality; } \\
\text { Directorate ties; }\end{array}$ & $\begin{array}{l}\text { Control Variables: Firm } \\
\text { Size; } R \& D \text { Intensity; } \\
\text { Advert Intensity; Prior } \\
\text { Performance. }\end{array}$ & $\begin{array}{l}\text { New Domestic } \\
\text { Ventures; New } \\
\text { Foreign } \\
\text { Investments. }\end{array}$ & $\begin{array}{l}\text { Agency Theory; } \\
\text { Stewardship } \\
\text { Theory. }\end{array}$ & $\begin{array}{l}\text { Non-Listed } \\
\text { Firms In India. }\end{array}$ & $\begin{array}{l}\text { Mapped neural director } \\
\text { interlock, sent director } \\
\text { interlocks, and received } \\
\text { director interlocks. }\end{array}$ \\
\hline 7 & $\begin{array}{l}\text { Seaman } e t \\
\text { al. [79] }\end{array}$ & $\begin{array}{l}\text { Empirical. } \\
\text { Primarily } \\
\text { exploratory } \\
\text { but also } \\
\text { descriptive. }\end{array}$ & $\begin{array}{l}\text { To explore the pattern of interlocks } \\
\text { cultivated by a rural family business } \\
\text { based on three types of social networks: } \\
\text { family, friendship, and business } \\
\text { networks. }\end{array}$ & $\begin{array}{l}\text { Interview data; Case } \\
\text { business records. } \\
\text { Individual level of } \\
\text { analysis. }\end{array}$ & $\begin{array}{l}\text { Family Interlocks; } \\
\text { Business Interlocks; } \\
\text { Friendship Interlocks. }\end{array}$ & Family Members & $\begin{array}{l}\text { Social Networks } \\
\text { of Business } \\
\text { Family. }\end{array}$ & $\begin{array}{l}\text { Multi-Rational } \\
\text { Network Theory. }\end{array}$ & $\begin{array}{l}1 \text { Rural Family } \\
\text { Business; } \\
\text { United } \\
\text { Kingdom. }\end{array}$ & $\begin{array}{l}\text { Identified three } \\
\text { interlocks in family } \\
\text { firms based on family, } \\
\text { friendship, and business } \\
\text { networks: sent, received } \\
\text { and neutral. }\end{array}$ \\
\hline 8 & $\begin{array}{l}\text { Naudet } \\
\text { and } \\
\text { Dubost } \\
{[80]}\end{array}$ & $\begin{array}{c}\text { Empirical. } \\
\text { Primarily } \\
\text { descriptive but } \\
\text { also } \\
\text { explanatory. }\end{array}$ & $\begin{array}{l}\text { To explain the context-influenced } \\
\text { emergence of interlocking directorates } \\
\text { in top Indian businesses in the period of } \\
\text { corporate governance reforms. }\end{array}$ & $\begin{array}{l}\text { Data from CMIE- } \\
\text { PROWESS and } \\
\text { Directors' Database, } \\
\text { India. Individual } \\
\text { level of analysis. }\end{array}$ & $\begin{array}{l}\text { Interlocking } \\
\text { Directorates }\end{array}$ & $\begin{array}{l}\text { Banks And Financial } \\
\text { Institutions; Family- } \\
\text { Owned Business } \\
\text { Houses; }\end{array}$ & $\begin{array}{l}\text { Corporate } \\
\text { Network } \\
\text { Density. }\end{array}$ & $\begin{array}{l}\text { Hegemony } \\
\text { Theory. }\end{array}$ & $\begin{array}{l}\text { Top } 250 \text { Listed } \\
\text { Firms, India. }\end{array}$ & $\begin{array}{l}\text { Focus is on the density } \\
\text { of received, sent, and } \\
\text { neutral directorate ties } \\
\text { and the emerging } \\
\text { corporate network. }\end{array}$ \\
\hline 9 & $\begin{array}{l}\text { Chen et al. } \\
\text { [82] }\end{array}$ & $\begin{array}{l}\text { Empirical. } \\
\text { Essentially } \\
\text { explanatory. }\end{array}$ & $\begin{array}{l}\text { To explore how the governance } \\
\text { structure in family-controlled firms } \\
\text { influences loan guarantee decisions } \\
\text { favouring related third parties. }\end{array}$ & $\begin{array}{l}\text { Data from Wind } \\
\text { database, CCER } \\
\text { database, Firms' } \\
\text { annual reports. } \\
\text { Individual level of } \\
\text { analysis. }\end{array}$ & $\begin{array}{l}\text { Non-Family Chairs } \\
\text { With Family Directors; } \\
\text { Family Chairs; } \\
\text { Interlocked Non- } \\
\text { Family Chairs }\end{array}$ & $\begin{array}{l}\text { Control Variables: } \\
\text { Growth Sales; Top } \\
\text { Share; Firm Age; CEO } \\
\text { Duality; Board Size. }\end{array}$ & $\begin{array}{l}\text { Related } \\
\text { Party Loan } \\
\text { Guarantees. }\end{array}$ & Agency Theory & $\begin{array}{l}\text { 1,785 Listed } \\
\text { Firms, China. }\end{array}$ & $\begin{array}{l}\text { Directors as sent } \\
\text { interlockers discreetly } \\
\text { provide interlock } \\
\text { advantages better than } \\
\text { CEOs as sent } \\
\text { interlockers due to } \\
\text { CEOs' visibility. }\end{array}$ \\
\hline
\end{tabular}


European Journal of Business and Management Research

www.ejbmr.org

\begin{tabular}{|c|c|c|c|c|c|c|c|c|c|c|}
\hline SN & $\begin{array}{c}\text { Author/ } \\
\text { Year }\end{array}$ & $\begin{array}{l}\text { Study Method } \\
\text { \& Type }\end{array}$ & Objective(s) & $\begin{array}{c}\text { Sources \& Unit of } \\
\text { Analysis }\end{array}$ & Predictor Variable & $\begin{array}{c}\text { Mediator/ } \\
\text { Moderator/CV }\end{array}$ & $\begin{array}{l}\text { Criterion } \\
\text { Variable } \\
\end{array}$ & $\begin{array}{c}\text { Underpinning } \\
\text { Theory }\end{array}$ & $\begin{array}{l}\text { Firm and } \\
\text { Country }\end{array}$ & $\begin{array}{l}\text { Typology of } \\
\text { Interlocks }\end{array}$ \\
\hline$\overline{\mid c 10}$ & $\begin{array}{l}\text { Cannella } \\
\text { et al. }[74]\end{array}$ & $\begin{array}{l}\text { Empirical. } \\
\text { Primarily } \\
\text { explanatory } \\
\text { but also } \\
\text { descriptive. }\end{array}$ & $\begin{array}{l}\text { Investigate how family businesses and } \\
\text { lone-founder businesses differ } \\
\text { concerning their unique desires for } \\
\text { control and influence and how these } \\
\text { differences are reflected in their board } \\
\text { structures. }\end{array}$ & $\begin{array}{l}\text { Compusat database; } \\
\text { EDGAR database. } \\
\text { Individual and } \\
\text { organisational levels } \\
\text { of analysis. }\end{array}$ & $\begin{array}{l}\text { Family Business; } \\
\text { Lone-Founder } \\
\text { Business; Public } \\
\text { Business. }\end{array}$ & $\begin{array}{l}\text { Control Variables: } \\
\text { Board Size; Director } \\
\text { Age; CEO Duality; } \\
\text { Firm Age; Firm } \\
\text { Performance. }\end{array}$ & $\begin{array}{l}\text { Directorate ties; } \\
\text { Prior } \\
\text { Experiences of } \\
\text { Directors; } \\
\text { Director Tenure. }\end{array}$ & $\begin{array}{l}\text { Social Identity } \\
\text { Theory; } \\
\text { Organisational } \\
\text { Identification } \\
\text { Theory. }\end{array}$ & $\begin{array}{l}\text { Listed Firms, } \\
\text { United States. }\end{array}$ & $\begin{array}{l}\text { Analysed the three forms } \\
\text { of interlocks: received } \\
\text { interlock, sent interlock, } \\
\text { and neutral interlock. }\end{array}$ \\
\hline 11 & $\begin{array}{l}\text { Bianco et } \\
\text { al. }[75]\end{array}$ & $\begin{array}{l}\text { Empirical. } \\
\text { Primarily } \\
\text { explanatory } \\
\text { but also } \\
\text { descriptive. }\end{array}$ & $\begin{array}{l}\text { To investigate family-affiliated women } \\
\text { representation on the boards of } \\
\text { directors of Italian firms before the } \\
\text { affirmative action legislation of } 2012 \\
\text { and its correlation with family } \\
\text { connections. }\end{array}$ & $\begin{array}{l}\text { Firm data from } \\
\text { Datastream } \\
\text { Worldscope. Director } \\
\text { data from survey. } \\
\text { Individual \& } \\
\text { organisational levels } \\
\text { of analysis. }\end{array}$ & $\begin{array}{l}\text { Ownership } \\
\text { Structure; Institutional } \\
\text { Investors; Board and } \\
\text { Director } \\
\text { Characteristics (e.g., } \\
\text { Interlocks). }\end{array}$ & $\begin{array}{l}\text { Control Variables: Firm } \\
\text { Size; Firm Age; Firm } \\
\text { Performance. }\end{array}$ & $\begin{array}{l}\text { Female } \\
\text { Directorship }\end{array}$ & $\begin{array}{l}\text { Agency Theory; } \\
\text { Resource } \\
\text { Dependence } \\
\text { Theory }\end{array}$ & $\begin{array}{l}\text { Listed Firms, } \\
\text { Italy. }\end{array}$ & $\begin{array}{l}\text { There are all three } \\
\text { interlocking types: } \\
\text { received interlock, sent } \\
\text { interlock, and neutral } \\
\text { interlock. }\end{array}$ \\
\hline 12 & $\begin{array}{l}\text { Bellenzier } \\
\text { and Grassi } \\
\quad[77]\end{array}$ & $\begin{array}{l}\text { Empirical. } \\
\text { Primarily } \\
\text { exploratory } \\
\text { but also } \\
\text { descriptive. }\end{array}$ & $\begin{array}{l}\text { To examine the evolution of } \\
\text { interlocking directorate over a } \\
\text { considerable time scale (1998-2011) } \\
\text { among Italian companies. }\end{array}$ & $\begin{array}{l}\text { Data from Assonime. } \\
\text { Organisational level } \\
\text { of analysis. }\end{array}$ & $\begin{array}{l}\text { Stability of Network } \\
\text { Structure Over Time. }\end{array}$ & $\begin{array}{l}\text { Ownership of a Few } \\
\text { Family Firms; Cross- } \\
\text { Shareholdings. }\end{array}$ & $\begin{array}{l}\text { Interlocking } \\
\text { Directorate }\end{array}$ & $\begin{array}{l}\text { Graph Theory; } \\
\text { Network Theory. }\end{array}$ & $\begin{array}{l}\text { Listed Firms, } \\
\text { Italy. }\end{array}$ & $\begin{array}{l}\text { Directorate ties in terms } \\
\text { of board network and } \\
\text { director network. }\end{array}$ \\
\hline 13 & $\begin{array}{l}\text { Piana } e t \\
a l .[62]\end{array}$ & $\begin{array}{l}\text { Empirical. } \\
\text { Primarily } \\
\text { exploratory } \\
\text { but also } \\
\text { descriptive. }\end{array}$ & $\begin{array}{l}\text { To assess corporate governance in a } \\
\text { Family Business Group based on the } \\
\text { firm's distinctive characteristics } \\
\text { (nature, type, intensity, and persistence } \\
\text { over time), shareholding and directorate } \\
\text { ties. }\end{array}$ & $\begin{array}{l}\text { Data from AIDA, } \\
\text { AMADEUS, Italian } \\
\text { Chamber of } \\
\text { Commerce; - } \\
\text { Organisational level } \\
\text { of analysis. }\end{array}$ & $\begin{array}{l}\text { Nature, Type, } \\
\text { Intensity, and } \\
\text { Persistence of Family } \\
\text { Business Group. }\end{array}$ & $\begin{array}{l}\text { Relational Structure } \\
\text { (Shareholdings); } \\
\text { Relational Texture } \\
\text { (Interlocking } \\
\text { Directorships). }\end{array}$ & $\begin{array}{l}\text { Corporate } \\
\text { Governance of a } \\
\text { Family Business } \\
\text { Group }\end{array}$ & $\begin{array}{l}\text { Agency Theory; } \\
\text { Stewardship } \\
\text { Theory. }\end{array}$ & $\begin{array}{l}\text { Non-Listed } \\
\text { Firm, Italy }\end{array}$ & $\begin{array}{l}\text { Mapped out the nature, } \\
\text { type, intensity, and } \\
\text { persistence of all three } \\
\text { forms of interlocking } \\
\text { directorships. }\end{array}$ \\
\hline 14 & $\begin{array}{l}\text { Lester and } \\
\text { Cannella } \\
\text { [73] }\end{array}$ & $\begin{array}{l}\text { Theoretical: } \\
\text { Conceptual. } \\
\text { Essentially } \\
\text { descriptive. }\end{array}$ & $\begin{array}{l}\text { To map out the types of directorate ties } \\
\text { family firms may use and show how the } \\
\text { interlocks can address intra-family } \\
\text { agency problems. }\end{array}$ & $\begin{array}{l}\text { Theoretical } \\
\text { propositions }\end{array}$ & $\begin{array}{l}\text { Family Controlled } \\
\text { Firms; Non-Family } \\
\text { Controlled Firms }\end{array}$ & $\begin{array}{l}\text { Interlocking } \\
\text { Directorates }\end{array}$ & $\begin{array}{l}\text { Strategic } \\
\text { Orientation; Firm } \\
\text { Performance }\end{array}$ & $\begin{array}{l}\text { Agency Theory; } \\
\text { Resource } \\
\text { Dependence } \\
\text { Theory }\end{array}$ & $\begin{array}{l}\text { Undefined } \\
\text { assumed to be } \\
\text { Listed }\end{array}$ & $\begin{array}{l}\text { Interlocking directorate } \\
\text { as a mechanism for } \\
\text { building business social } \\
\text { capital. }\end{array}$ \\
\hline 15 & $\begin{array}{c}\text { Chua et al. } \\
\text { [81] }\end{array}$ & $\begin{array}{l}\text { Theoretical: } \\
\text { Commentary. } \\
\text { Essentially } \\
\text { descriptive. }\end{array}$ & $\begin{array}{l}\text { Extended Lester and Cannella [73] for a } \\
\text { better understanding of directorate ties } \\
\text { in family businesses. }\end{array}$ & $\begin{array}{l}\text { Theoretical } \\
\text { propositions. }\end{array}$ & Family Firms & $\begin{array}{l}\text { Shared Values; Trust; } \\
\text { Resource Sharing. } \\
\text { Geogra-phical Distance }\end{array}$ & $\begin{array}{l}\text { Director } \\
\text { Interlocks }\end{array}$ & $\begin{array}{l}\text { Agency Costs } \\
\text { Theory }\end{array}$ & $\begin{array}{l}\text { Undefined } \\
\text { assumed to be } \\
\text { Listed }\end{array}$ & $\begin{array}{l}\text { New propositions on } \\
\text { received, sent, and } \\
\text { neutral directorate ties. }\end{array}$ \\
\hline 16 & $\begin{array}{l}\text { Beachy } \\
{[70]}\end{array}$ & $\begin{array}{l}\text { Archival. } \\
\text { Organisational } \\
\text { Historiograph } \\
\text { y. Essentially } \\
\text { descriptive. }\end{array}$ & $\begin{array}{l}\text { Show how practices of family-based } \\
\text { enterprise shaped the legal and social } \\
\text { structures that allowed for women } \\
\text { economic participation in Central } \\
\text { Europe between } 1650-1880 \text {. }\end{array}$ & $\begin{array}{l}\text { Archival sources. } \\
\text { The family as a } \\
\text { business unit; } \\
\text { Individual level of } \\
\text { analysis. }\end{array}$ & $\begin{array}{l}\text { Economic Agency (as } \\
\text { discussed in the } \\
\text { paper). }\end{array}$ & $\begin{array}{l}\text { Evolution of Legal } \\
\text { Female Legal Rights to } \\
\text { Engage in Commerce }\end{array}$ & $\begin{array}{l}\text { Women } \\
\text { Participation in } \\
\text { Economic } \\
\text { Activities based } \\
\text { on Links } \\
\text { (Interlocks). }\end{array}$ & $\begin{array}{l}\text { Gender Role } \\
\text { Theory (implied } \\
\text { in the paper). }\end{array}$ & $\begin{array}{l}\text { Early Form of } \\
\text { Family } \\
\text { Business, } \\
\text { Germany }\end{array}$ & $\begin{array}{l}\text { Female interlocking } \\
\text { directorate as a } \\
\text { mechanism for the long- } \\
\text { term survival of family } \\
\text { firms in Germany, 1650- } \\
1880 .\end{array}$ \\
\hline 17 & Zang [78] & $\begin{array}{l}\text { Empirical. } \\
\text { Essentially } \\
\text { explanatory. }\end{array}$ & $\begin{array}{l}\text { To examine inter-firm connectedness } \\
\text { among large Chinese family businesses } \\
\text { in Singapore. }\end{array}$ & $\begin{array}{l}\text { Published and survey } \\
\text { data: Singapore 500 } \\
\text { (1987), Singapore } \\
500 \text { (1988), } \\
\text { Singapore 1,000 } \\
\text { (1991) }\end{array}$ & $\begin{array}{l}\text { Family Control and } \\
\text { Reputation (Family } \\
\text { Firm; Firm Size, Age } \\
\text { \& Solvency; Long- } \\
\text { Term Debt; Trade } \\
\text { Credit). }\end{array}$ & None & $\begin{array}{l}\text { Interlocking } \\
\text { Directorships } \\
\text { (Number of } \\
\text { Inter-Corporate } \\
\text { Ties as of 1992) }\end{array}$ & $\begin{array}{l}\text { Resource } \\
\text { Dependence } \\
\text { Theory; } \\
\text { Hegemony } \\
\text { Theory; Network } \\
\text { Theory. } \\
\end{array}$ & $\begin{array}{l}107 \text { Listed } \\
\text { Firms; } \\
\text { Singapore }\end{array}$ & $\begin{array}{l}\text { Directorate ties informed } \\
\text { by sent interlocker and } \\
\text { few received } \\
\text { interlockers. Strategic } \\
\text { use of neutral } \\
\text { interlockers. }\end{array}$ \\
\hline
\end{tabular}




\section{REFERENCES}

[1] M. Fennema and H. Schijf, "Analysing interlocking directorates: Theory and methods," Social Networks, vol. 1, no. 4, pp. 297-332, 1978.

[2] F. H. Dixon, "The Economic Significance of Interlocking Directorates in Railway Finance," Journal of Political Economy, vol. 22, no. 10, pp. 937-954, 1914.

[3] E. D. Durand, "The Trust Legislation of 1914," The Quarterly Journal of Economics, vol. 29, no. 1, pp. 72-97, 1914.

[4] K. Kirkpatrick, "Publication trends of interlocking directorate studies," The American Sociologist, vol. 21, no. 3, pp. 257-270, 1990.

[5] R. Caiazza and M. Simoni, "Directorate ties: a bibliometric analysis," Management Decision, vol. 57, no. 10, pp. 2837-2851, 2019.

[6] C. Helmers, M. Patnam, and P. R. Rau, "Do board interlocks increase innovation? Evidence from a corporate governance reform in India," Journal of Banking \& Finance, vol. 80, pp. 51-70, 2017.

[7] G. F. Davis, "The Significance of Board Interlocks for Corporate Governance," Corporate Governance: An International Review, vol. 4, no. 3, pp. 154-159, 1996.

[8] E. M. Azila-Gbettor, B. Q. Honyenuga, R. J. Blomme, and A. Kil, "Review of differences between listed and unlisted family business research trends: a corporate governance context," (in English), Journal of Family Business Management, vol. ahead-of-print, no. ahead-ofprint, pp. 1-23, Apr 292021.

[9] R. S. Burt, S. Opper, and N. Zou, "Social network and family business: Uncovering hybrid family firms," Social Networks, vol. 65, pp. 141156, 2021.

[10] R. S. Burt, Corporate Profits and Cooptation: Networks of Market Constraints and Directorate Ties in the American Economy. New York, NY: Academic Press, Inc., 1983.

[11] B. Bird, H. Welsch, J. H. Astrachan, and D. Pistrui, "Family Business Research: The Evolution of an Academic Field," Family Business Review, vol. 15, no. 4, pp. 337-350, 2002.

[12] M. C. Shanker and J. H. Astrachan, "Myths and Realities: Family Businesses' Contribution to the US Economy- A Framework for Assessing Family Business Statistics," Family Business Review, vol. 9, no. 2, pp. 107-123, 1996.

[13] I. F. Ansari, M. Goergen, and S. Mira, "How Reported Board Independence Overstates Actual Board Independence in Family Firms: A Methodological Concern," Annals of Corporate Governance, vol. 3, no. 8, pp. 82-183, 2018.

[14] E. Johnsen and B. Mintz, "Organizational versus Class Components of Director Networks," in Networks of Power: Organizational Actors at the National, Corporate, and Community Levels, R. Perrucci and H. R. Potter, Eds. Hawthorne, New York: Aldine de Gruyter, 1989, pp. $57-$ 80.

[15] E. M. Heemskerk, Decline of the Corporate Community: Network Dynamics of the Dutch Business Elite. Amsterdam: Amsterdam University Press, 2007.

[16] M. C. Withers, M. D. Howard, and L. Tihanyi, "You've Got a Friend: Examining Board Interlock Formation After Financial Restatements," Organization Science, vol. ahead-of-print, no. ahead-of-print, pp. 1-29, 2020.

[17] M. T. Nguyen, "The impact of political connection on firm performance: empirical evidence from Vietnamese listed companies in manufacturing sector," PhD Thesis, Bournemouth University, Bournemouth, Dorset, England, 2020.

[18] J. Chu and J. Davis, "When board interlock fell apart, so did political moderation in the boardroom," vol. 2020, ed, 2017.

[19] L. N. Wati, H. I. Primiana, K. Pirzada, and R. Sudarsono, "Political connection, blockholder ownership and performance," Entrepreneurship and Sustainability Issues, vol. 7, no. 1, pp. 52-68, 2019.

[20] R. Nason, A. Mazzelli, and M. Carney, "The Ties That Unbind: Socialization and Business-Owning Family Reference Point Shift," Academy of Management Review, vol. 44, no. 4, pp. 846-870, 2019.

[21] N. Mans-Kemp, S. Viviers, and S. Collins, "Exploring the causes and consequences of director overboardedness in an emerging market," International Journal of Disclosure and Governance, vol. 15, no. 4, pp. 210-220, 2018.

[22] Y. Teng, E. Gimmon, and W. Lu, "Do Interlocks Lead to the Convergence of Interfirm Innovation Performance? Evidence From China," SAGE Open, vol. 11, no. 2, pp. 1-20, 2021.

[23] D. Valeeva, E. M. Heemskerk, and F. W. Takes, "The duality of firms and directors in board interlock networks: A relational event modeling approach," Social Networks, vol. 62, pp. 68-79, 2020.

[24] S.-H. Lee, P. H. Phan, and H.-b. Ding, "A theory of family employee involvement during resource paucity," Journal of Family Business Strategy, vol. 7, no. 3, pp. 160-166, 2016.
[25] F. Zona, B. K. Boyd, and K. Takacs Haynes, "Coordination, control, or charade? The role of board interlocks among business group members," Management Decision, vol. 57, no. 10, pp. 2630-2652, 2019.

[26] A. Klobuchar, Antitrust: Taking on Monopoly Power from the Gilded Age to the Digital Age. New York: Alfred A. Knopf, 2021.

[27] (2017). Amended on 20/5/2019 by Resolution of the Board of the Capital Market Authority Number 3-57-2019, Corporate Governance Regulations.

[28] M. Zeitlin, "Corporate Ownership and Control: The Large Corporation and the Capitalist Class," American Journal of Sociology, vol. 79, no. 5, pp. 1073-1119, 1974.

[29] F. Lundberg, Ameriaca's 60 Families. New York: The New Vanguard Press, 1937.

[30] R. Pranckute, "Web of Science (WoS) and Scopus: The Titans of Bibliographic Information in Today's Academic World," Publications, vol. 9 , no. 1, pp. 12-, 2021

[31] G. Budimir, S. Rahimeh, S. Tamimi, and P. Južnič, "Comparison of self-citation patterns in WoS and Scopus databases based on national scientific production in Slovenia (1996-2020)," Scientometrics, vol. 126, no. 3, pp. 2249-2267, 2021.

[32] JASP Team, "JASP," 0.14.1 ed, 2020.

[33] D. Tunger and J. Wilhelm, "The bibliometric community as reflected by its own methodology," Journal of Scientometric Research, vol. 2, no. 2, pp. 92-101, 2013.

[34] E. A. Abdul Wahab, M. F. Jamaludin, D. Agustia, and I. Harymawan, "Director Networks, Political Connections, and Earnings Quality in Malaysia," Management and Organization Review, vol. 16, no. 3, pp. 687-724, 2020.

[35] Y. Wu and B. Dong, "Independent director network and corporate innovation: evidence from a natural experiment in China," Applied Economics Letters, vol. 28, no. 7, pp. 559-564, 2021.

[36] M. A. Joshi, "Bibliometric indicators for evaluating the quality of scientifc publications," The Journal of Contemporary Dental Practice, vol. 15, no. 2, pp. 258-262, Mar 12014.

[37] J. Brennecke and O. N. Rank, "Tie heterogeneity in networks of interlocking directorates: a cost-benefit approach to firms' tie choice," Business Research, vol. 10, no. 1, pp. 97-122, 2017.

[38] M. Szomszor et al., "Interpreting Bibliometric Data," Frontiers in Research Metrics and Analytics, vol. 5, pp. 1-20, 2021.

[39] P. V. Kamat, "Impact Factor, CiteScore, and Citation Analysis," ACS Energy Letters, vol. 5, no. 7, pp. 2452-2453, 2020.

[40] C. James, L. Colledge, W. Meester, N. Azoulay, and A. Plume, "CiteScore metrics: Creating journal metrics from the Scopus citation index," Learned Publishing, vol. 32, no. 4, pp. 367-374, 2019.

[41] E. Roldan-Valadez, S. Y. Salazar-Ruiz, R. Ibarra-Contreras, and C. Rios, "Current concepts on bibliometrics: a brief review about impact factor, Eigenfactor score, CiteScore, SCImago Journal Rank, SourceNormalised Impact per Paper, H-index, and alternative metrics," Ir J Med Sci, vol. 188, no. 3, pp. 939-951, Aug 2019.

[42] S. S. Vijayan and V. R. Renjith, "Visualization of Library and Information Science (LIS) Journals in SCImago: An Analysis of First Quartile (Q1) Journals," Library Philosophy and Practice (e-journal), vol. 2021, no. 5775, pp. 1-16, 2021.

[43] A. Wooditch, N. J. Johnson, R. Solymosi, J. Medina Ariza, and S. Langton, "Bivariate Correlation," in A Beginner's Guide to Statistics for Criminology and Criminal Justice Using R, A. Wooditch, N. J. Johnson, R. Solymosi, J. M. Ariza, and S. Langton, Eds. Cham, Switzerland: Springer International Publishing, 2021, pp. 227-244.

[44] S. S. Shapiro and M. B. Wilk, "An analysis of variance test for normality (complete samples)," Biometrika, vol. 52, no. 3 and 4, pp. 591-611, 1965

[45] G. Haynes et al., "Family business research: Reviewing the past, contemplating the future," Journal of Family and Economic Issues, vol. 42, no. Suppl 1, pp. S70-S83, Oct 312021.

[46] H. C. Fang, K. Singh, T. Kim, L. Marler, and J. J. Chrisman, "Family business research in Asia: review and future directions," Asia Pacific Journal of Management, pp. 1-42, 2021.

[47] J. C. Short, P. Sharma, G. T. Lumpkin, and A. W. Pearson, "Oh, the Places We'll Go! Reviewing Past, Present, and Future Possibilities in Family Business Research," Family Business Review, vol. 29, no. 1, pp. 11-16, 2016.

[48] J.-F. Siebels and D. zu Knyphausen-Aufseß, "A Review of Theory in Family Business Research: The Implications for Corporate Governance," International Journal of Management Reviews, vol. 14, no. 3, pp. 280-304, 2012.

[49] J. E. Jennings, R. S. Breitkreuz, and A. E. James, "Theories from Family Science: A Review and Roadmap for Family Business Research," in The SAGE Handbook of Family Business, L. Melin, M. Nordqvist, and P. Sharma, Eds. London: SAGE Publications Inc., 2004, pp. 25-46. 
[50] R. Arteaga and A. Escribá-Esteve, "Heterogeneity in family firms: contextualising the adoption of family governance mechanisms," Journal of Family Business Management, vol. 11, no. 2, pp. 200-222, 2020.

[51] F. W. Andersson, D. Johansson, J. Karlsson, M. Lodefalk, and A. Poldahl, "The characteristics of family firms: exploiting information on ownership, kinship, and governance using total population data," Small Business Economics, vol. 51, no. 3, pp. 539-556, 2017.

[52] M. Güldenkoh and U. Silberg, "The characteristics of family businesses: A comparative analysis of East European countries," Estonian Discussions on Economic Policy, vol. 27, no. 1-2, pp. 63-82, 2019.

[53] D. Alrubaishi, M. McAdam, and R. Harrison, "Culture, Islamic capital and the entrepreneurial behaviour of family firms in Saudi Arabia," International Journal of Entrepreneurial Behavior \& Research, vol ahead-of-print, no. ahead-of-print, pp. 1-26, 2021.

[54] O. Machek, "Where have all the countries of origin gone? A note on the neglect of firm nationality in family business studies," Journal of Family Business Management, vol. 8, no. 3, pp. 331-338, 2018.

[55] IFERA, "Family Businesses Dominate," Family Business Review, vol. 16, no. 4, pp. 235-240, 2003.

[56] T. M. Pieper, F. W. Kellermanns, and J. H. Astrachan, Update 2021: Family Businesses' Contribution to the U.S. Economy. Washington, DC: Family Enterprise USA, 2021.

[57] M. S. Mizruchi, The Fracturing of the American Corporate Elite. Cambridge, Massachusetts: Harvard University Press, 2013.

[58] S. Yazdani, A. Shirvani, and P. Heidarpoor, "A Model for the Taxonomy of Research Studies: A Practical Guide to Knowledge Production and Knowledge Management," Archives of Pediatric Infectious Diseases, vol. In Press, no. In Press, pp. 1-9, 2021.

[59] P. Biecek and T. Burzykowski, Explanatory Model Analysis: Explore, Explain, and Examine Predictive Models. Boca Raton, FL: CRC Press, 2021

[60] S. Jain, Research Methodology in Arts, Science and Humanities. Oakville, ON, Canada: Society Publishing, 2019.

[61] S. L. Siedlecki, "Understanding Descriptive Research Designs and Methods," Clinical Nurse Specialist, vol. 34, no. 1, pp. 8-12, Jan/Feb 2020.

[62] B. D. Piana, A. Vecchi, and C. Cacia, "Towards a better understanding of Family Business Groups and their key dimensions," Journal of Family Business Strategy, vol. 3, no. 3, pp. 174-192, 2012

[63] W. Gibb Dyer and M. Sánchez, "Current State of Family Business Theory and Practice as Reflected in Family Business Review 19881997," Family Business Review, vol. 11, no. 4, pp. 287-295, 1998.

[64] C. Kivunja, "Distinguishing between Theory, Theoretical Framework, and Conceptual Framework: A Systematic Review of Lessons from the Field," International Journal of Higher Education, vol. 7, no. 6, 2018.

[65] S. A. Zahra, "Developing theory-grounded family business research: Some suggestions," Journal of Family Business Strategy, vol. 7, no. 1, pp. 3-7, 2016.

[66] M. Berge and $\AA$. Ingerman, "Multiple theoretical lenses as an analytical strategy in researching group discussions," Research in Science \& Technological Education, vol. 35, no. 1, pp. 42-57, 2017.

[67] P. Cairney, "Standing on the Shoulders of Giants: How Do We Combine the Insights of Multiple Theories in Public Policy Studies?," Policy Studies Journal, vol. 41, no. 1, pp. 1-21, 2013.

[68] F. Zona, L. R. Gomez-Mejia, and M. C. Withers, "Board Interlocks and Firm Performance: Toward a Combined Agency-Resource Dependence Perspective," Journal of Management, vol. 44, no. 2, pp. 589-618, 2018.

[69] W. Schulze and T. M. Zellweger, "Property Rights, OwnerManagement, and Value Creation," Academy of Management Review, vol. 00, no. 0, 2020.

[70] R. Beachy, "Business was a family affair: Women of commerce in central Europe, 1650-1880," Histoire sociale / Social History, vol. 34, no. 68 , pp. 307-330, 2001.

[71] R. Suddaby, B. S. Silverman, A. De Massis, P. Jaskiewicz, and E. R. Micelotta, "Call for Papers for the 2023 Family Business Review (FBR) Special Issue on History-informed Family Business Research," Family Business Review, vol. 33, no. 3, pp. 331-334, 2020.

[72] E. R. Kushins and E. Behounek, "Using sociological theory to problematize family business research," Journal of Family Business Strategy, vol. 11, no. 1, 2020.

[73] R. H. Lester and A. A. Cannella, "Interorganizational Familiness: How Family Firms Use Interlocking Directorates to Build CommunityLevel Social Capital," Entrepreneurship Theory and Practice, vol. 30, no. 6, pp. 755-775, 2006.

[74] A. A. Cannella, C. D. Jones, and M. C. Withers, "Family- versus LoneFounder-Controlled Public Corporations: Social Identity Theory and
Boards of Directors," Academy of Management Journal, vol. 58, no. 2, pp. 436-459, 2015

[75] M. Bianco, A. Ciavarella, and R. Signoretti, "Women on Corporate Boards in Italy: The Role of Family Connections," Corporate Governance: An International Review, vol. 23, no. 2, pp. 129-144, 2015.

[76] D. Singh and A. Delios, "Corporate governance, board networks and growth in domestic and international markets: Evidence from India," Journal of World Business, vol. 52, no. 5, pp. 615-627, 2017.

[77] L. Bellenzier and R. Grassi, "Interlocking directorates in Italy: persistent links in network dynamics," Journal of Economic Interaction and Coordination, vol. 9, no. 2, pp. 183-202, 2014.

[78] X. Zang, "Research Note: Personalism and Corporate Networks in Singapore," Organization Studies, vol. 20, no. 5, pp. 861-877, 1999.

[79] C. Seaman, R. McQuaid, and M. Pearson, "Social networking in family businesses in a local economy," Local Economy: The Journal of the Local Economy Policy Unit, vol. 32, no. 5, pp. 451-466, 2017

[80] J. Naudet and C.-L. Dubost, "The Indian exception: the densification of the network of corporate interlocks and the specificities of the Indian business system (2000-2012)," Socio-Economic Review, vol. 15, no. 2 , pp. 405-434, 2017.

[81] J. H. Chua, L. P. Steier, and J. J. Chrisman, "How Family Firms Solve Intra-Family Agency Problems Using Interlocking Directorates: An Extension," Entrepreneurship: Theory and Practice, vol. 30, no. 6, pp. 777-783, 2006

[82] X. Chen, J. Arnoldi, and C. Na, "Governance Structure and Related Party Loan Guarantees: The Case of Chinese Family Business Groups," Management and Organization Review, vol. 11, no. 4, pp. 599-619, 2015.

[83] J. Naudet, A. Allorant, and M. Ferry, "Heirs, corporate aristocrats and 'Meritocrats': the social space of top CEOs and Chairmen in India," Socio-Economic Review, vol. 16, no. 2, pp. 307-339, 2018.

[84] F. Rubino and F. Napoli, "What Impact Does Corporate Governance Have on Corporate Environmental Performances? An Empirical Study of Italian Listed Firms," Sustainability, vol. 12, no. 14, pp. 5742-5762, 2020.

[85] V. Sanchez-Famoso, J.-H. Mejia-Morelos, and L. Cisneros, "New Insights into Non-Listed Family SMEs in Spain: Board Social Capital, Board Effectiveness, and Sustainable Performance," Sustainability, vol. 12 , no. 3 , pp. 814-831, 2020.

[86] V. S. Panicker and R. S. Upadhyayula, "Limiting role of resource dependence: an examination of director interlocks, board meetings and family ownership," Cross Cultural \& Strategic Management, vol. 28, no. 2, pp. 424-451, 2020.

[87] R. Anand and B. Singh, "Effect of Composition of Board and Promoter Group Retained Ownership on Underpricing of Indian IPO firms: An Empirical Study," Indian Journal of Corporate Governance, vol. 12 , no. 1 , pp. 21-38, 2019.

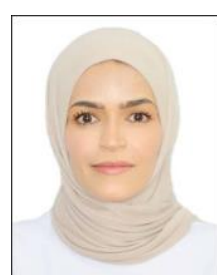

Algthami, Nawar Muneer $\mathbf{J}$ obtained her Bachelors in Accounting from King Abdulaziz University, Jeddah, Saudi Arabia, in 2005, and a Masters in Accounting and Finance from the University of Wolverhampton, United Kingdom, in 2017. She had served as an accounting teacher with Taif University, Saudi Arabia, and had volunteered as an Assistant in Business Administration at King Abdulaziz University, Jeddah. Nawar is now a doctoral student at the Azman Hashim International Business School, Universiti Teknologi Malaysia, Kuala Lumpur, Malaysia

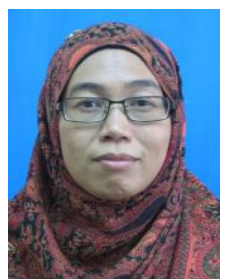

Dr Nazimah Hussin is an Associate Professor at Azman Hashim International Business School, Universiti Teknologi Malaysia. She bagged a $\mathrm{PhD}$ from Durham University, an MSc from Loughborough University, and a BSc from Arizona State University. She has more than 17 years of teaching and research experience. She has been awarded fellowship of the Higher Education Academy and has completed several research grants. Dr Nazimah supervises $\mathrm{PhD}$ and Master students and has graduated several of them. She is an examiner, panellist, chairperson, and reviewer relating to academic activities, especially postgraduate studies. She produces research articles related to Islamic Finance and Service Marketing and has published more than 30 articles in refereed indexed journals. 